\title{
Differential Distribution of Intracellular Glutamate Receptors in Dendrites
}

\author{
Maria E. Rubio and Robert J. Wenthold \\ Laboratory of Neurochemistry, National Institute on Deafness and Other Communication Disorders, National Institutes of \\ Health, Bethesda, Maryland 20892
}

Glutamate receptors are synthesized in the cell body and transported in intracellular compartments to the target synapse. The objective of the present study was to analyze the intracellular pool of glutamate receptors and determine whether the intracellular pool was related to the synaptic distribution of the receptors. As a model system, we chose the fusiform cell of the dorsal cochlear nucleus for which we have previously demonstrated that receptors are selectively targeted to synapses on apical and basal dendrites. A combination of retrograde tracing and postembedding immunogold labeling was used to quantify intracellular receptors in segments of apical and basal dendrites. Immunolabeling for GluR4 and mGluR1 $\alpha$ is present at synapses on basal dendrites but not on apical dendrites, whereas immunolabeling for GluR2/3 is present at both populations of synapses. In the analysis of intracellular pools, we find that GluR2/3 is equally distributed in apical and basal dendrites, whereas GluR4 and mGluR $1 \alpha$ are more concentrated in basal dendrites than in apical dendrites. These findings indicate that the distribution of intracellular receptors is related to that of synaptic receptors and suggest that a mechanism exists in neurons to target proteins to dendritic domains soon after synthesis. We found no evidence for the existence of a pool of intracellular receptors, which could represent a receptor reserve, near the postsynaptic density. Receptors were often found in clusters associated with tubulovesicular membranes of the endoplasmic reticulum, identified with immunoglobulin binding protein (BIP) or calnexin, suggesting that this organelle is involved in receptor transport in dendrites.

Key words: glutamate receptor; immunocytochemistry; dendrite; postembedding; targeting; cochlear nucleus
The selective targeting of neurotransmitter receptors to the postsynaptic plasma membrane is a fundamentally important but poorly understood process. Like other integral membrane proteins associated with the plasma membrane, receptors are synthesized predominantly in the cell body (Eshhar et al., 1993) and transported by way of intracellular organelles to the postsynaptic membrane where they form functional receptor complexes. Neurons are polarized cells with functionally and morphologically distinct axonal and somatodendritic domains, and proteins destined to occupy the different domains are sorted in the cell body after synthesis (Kelly and Grote, 1993). However, within these two domains, the protein distribution is by no means uniform. This is particularly evident in the somatodendritic compartment where multiple synaptic inputs are found, often involving different neurotransmitters. Functional and distribution studies have confirmed that the appropriate neurotransmitter receptor is found postsynaptic to terminals releasing the corresponding neurotransmitter, showing that a mechanism must exist to ensure the proper location of a postsynaptic receptor (for review, see Petralia, 1997; Somogyi et al., 1998).

However, the complexity of the protein organization in the somatodendritic compartment extends beyond that of placing the

Received Feb. 12, 1999; revised March 31, 1999; accepted April 8, 1999.

This study was supported by the National Institute of Deafness and Other Communication Disorders Intramural Program. We thank Drs. O. P. Ottersen and R. S. Petralia for reading and helpful comments, and Drs. J. Fex and D. Wu for reviewing this manuscript. We thank Dr. D. R. Hampson for kindly providing us with the polyclonal antibody (Ab-3) for mGluR1 $\alpha$.

Correspondence should be addressed to Maria E. Rubio, National Institute on Deafness and Other Communication Disorders, National Institutes of Health, Building 36, Room 5D08, 36 Convent Drive, Bethesda, MD 20892-4162.

Copyright (C) 1999 Society for Neuroscience $0270-6474 / 99 / 195549-14 \$ 05.00 / 0$ appropriate receptor at a particular synapse. The receptor families for most transmitters are complex, with multiple subtypes and subunits of any particular receptor expressed in any one neuron. Although this increases the potential diversity of a receptor family by allowing the neuron to place different combinations of receptors at different synaptic populations, it also increases the complexity of the targeting mechanisms necessary to achieve these distributions. To investigate the organization of glutamate receptors in neurons receiving multiple excitatory inputs, we have studied fusiform cells (FCs) of the dorsal cochlear nucleus that receive two different glutamatergic inputs. In FCs, GluR4 and mGluR $1 \alpha$ are found only at auditory nerve synapses but not at parallel fiber synapses (Rubio and Wenthold, 1997a). One mechanism by which a selective synaptic expression of a receptor may be achieved would be to use a synaptic anchor that stabilizes a receptor at the postsynaptic site. The discovery of the PSD95/ SAP90 family of proteins (for review, see Kennedy, 1997) and their interaction with NMDA receptors (Kornau et al., 1995; Kim et al., 1996) support the idea that an anchoring protein at a synapse may determine the expression of the receptor.

An alternative mechanism for achieving selective synaptic expression of a receptor involves the specific targeting of the intracellular organelles that contain receptors to a particular synaptic population. Both biochemical and immunocytochemical approaches have shown that a significant amount of most glutamate receptor subunits is present in the cytoplasm of neuronal cell bodies (for review, see Petralia, 1997). In the present study we characterized the distribution of these intracellular receptors to determine whether the intracellular distribution is related to the synaptic distribution of the receptor. If this intracellular distribution is not organized in the dendritic compartment, it would 


\begin{tabular}{|c|c|c|c|c|}
\hline $\begin{array}{l}\text { Receptor/ } \\
\text { antibody }\end{array}$ & Region & Amino acid sequence of peptide antigen & $\begin{array}{l}\text { Concentration } \\
\text { postembedding }\end{array}$ & Reference \\
\hline \multicolumn{5}{|l|}{ AMPA } \\
\hline GluR1 & C terminus & SHSSGMPLGATGL (877-889) & $4.0 \mu \mathrm{g} / \mathrm{ml}$ & Wenthold et al. (1992) \\
\hline GluR2 & C terminus & VAKNPQNINPSSSQNS (827-842) & $4.0 \mu \mathrm{g} / \mathrm{ml}$ & Petralia et al. (1997b) \\
\hline GluR2/3 & C terminus & EGYNVYGIESVKI (850-862) & $2.5 \mu \mathrm{g} / \mathrm{ml}$ & Wenthold et al. (1992) \\
\hline GluR4 & C terminus & RQSSGLAVIASDLP (868-881) & $2.0 \mu \mathrm{g} / \mathrm{ml}$ & Wenthold et al. (1992) \\
\hline \multicolumn{5}{|l|}{$\begin{array}{c}\text { Metabotropic } \\
\text { mGluR1 } \alpha\end{array}$} \\
\hline Ab-1 H3-2 & C terminus & PNVTYASVILRDYKQSSSTL (1180-1199) & $5.0 \mu \mathrm{g} / \mathrm{ml}$ & Petralia et al. (1996) \\
\hline $\mathrm{Ab}-290^{a}$ & C terminus & $842-1200$ & 1:10 dilution & Petralia et al. (1997a) \\
\hline Ab-3 A4 & C terminus & EFVYEREGNTEEDEL (1117-1130) & $1: 100$ & Baude et al. (1993) \\
\hline $\mathrm{BiP}^{a}$ & $\mathrm{C}$ terminus & KSEKDEL & 1:200 dilution & $\begin{array}{l}\text { StressGen, Victoria, Brit- } \\
\text { ish Columbia, Canada }\end{array}$ \\
\hline Calnexin & C terminus & AEEDEILNRSPRNRKPRRE (555-573) & $6.0 \mu \mathrm{g} / \mathrm{ml}$ & $\begin{array}{l}\text { Rubio and Wenthold } \\
\text { (1997b) }\end{array}$ \\
\hline
\end{tabular}

\footnotetext{
${ }^{a}$ Monoclonal antibodies.
}

suggest that receptor-containing organelles are indiscriminately transported to dendritic locations and that a local process, such as the interaction with a synaptic anchor, is the critical factor in controlling synaptic expression. On the other hand, if an intracellular pattern is found that is related to the synaptic expression pattern, it would suggest that the targeting of the organelles may play a role in the synaptic expression. To determine the answer to this question, we studied the distribution of intracellular glutamate receptors in FCs of the dorsal cochlear nucleus for which we have previously shown that glutamate receptors are differentially expressed at synapses in the apical and basal dendrites. Our results show that the intracellular distribution of receptors is related to the synaptic distribution.

\section{MATERIALS AND METHODS}

Antibodies. The antibodies used in this study are shown in Table 1. All of them have been thoroughly characterized and widely used for immunocytochemical localization of glutamate receptors with light microscopy and pre-embedding and postembedding immunocytochemistry (Wenthold et al., 1992; Petralia et al., 1996, 1997a,b; Rubio and Wenthold, 1997a,b). The monoclonal antibody to immunoglobulin binding protein (BiP) was obtained commercially (StressGen, Victoria, British Columbia, Canada). A polyclonal antibody to the $\mathrm{C}$ terminus of mGluR $1 \alpha$ was kindly provided by Dr. David Hampson (University of Toronto) [described in detail in Baude et al. (1993)].

Retrograde labeling with horseradish peroxidase and tissue preparation. Six Sprague Dawley rats were used for freeze-substitution immunogold labeling. Retrograde labeling with horseradish peroxidase (HRP) [developed with 3',3-diamino benzidine tetrahydrochloride (DAB)] and tissue preparation are described in detail in Rubio and Wenthold (1997a). Animals were perfused for 5-10 min with $200 \mathrm{ml}$ of a fixative consisting of $4 \%$ paraformaldehyde and $0.5 \%$ glutaraldehyde in $0.12 \mathrm{M}$

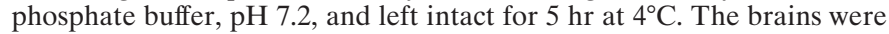
then removed and fixed in the same fixative for an additional $30 \mathrm{~min}$ at $4^{\circ} \mathrm{C}$. They were rinsed in three changes of $0.1 \mathrm{M}$ phosphate buffer, $\mathrm{pH} 7.2$, containing $4 \%$ glucose and stored overnight at $4{ }^{\circ} \mathrm{C}$ in the same buffer. Sagittal sections $(150 \mu \mathrm{m})$ of the brain were cut in cold $0.1 \mathrm{M}$ phosphate buffer, $\mathrm{pH} 7.2$, containing $4 \%$ glucose, with a vibratome. Agarose (1\%) in PBS was usually used to support the brains. The use and care of the animals in this study followed the guidelines of the National Institutes of Health Animal Research Advisory Committee.

Freeze substitution and immunogold labeling. The freeze substitution and postembedding immunogold technique for glutamate receptors, as described in detail by Matsubara et al. (1996) and Rubio and Wenthold (1997a), was used. Freeze substitution and low-temperature embedding of the sections in a methacrylate resin were performed (van Lookeren Campagne et al., 1991; Hjelle et al., 1994; Chaudhry et al., 1995). Briefly, the sections were cryoprotected by immersion in graded concentrations of glycerol $(10,20$, and $30 \%)$ in $0.1 \mathrm{M}$ phosphate buffer and plunged rapidly into liquid propane $\left(-184^{\circ} \mathrm{C}\right)$ cooled by liquid nitrogen in a Leica EM CPC cryofixation unit (Reichert, Vienna, Austria). The samples were immersed in $0.5 \%$ uranyl acetate dissolved in anhydrous methanol $\left(-90^{\circ} \mathrm{C}, 24 \mathrm{hr}\right)$ in an AFS cryosubstitution unit (Reichert). The temperature was raised in steps of $4^{\circ} \mathrm{C} / \mathrm{hr}$ from $-90^{\circ}$ to $-45^{\circ} \mathrm{C}$. The samples were washed three times with anhydrous methanol and infiltrated with Lowicryl HM20 resin (Polyscience, Warrington, PA) at $-45^{\circ} \mathrm{C}$, with a progressive increase in the ratio of resin to methanol. Polymerization was performed with ultraviolet light $(360 \mathrm{~nm})$ for $48 \mathrm{hr}$.

Postembedding immunocytochemistry. Colloidal gold-coupled goat anti-rabbit IgG (5 nm GAR G5 and $10 \mathrm{~nm}$ GAR G10; Amersham, Arlington Heights, IL) was used to detect rabbit polyclonal antibodies and goat anti-mouse IgG (5 nm GAM G5, $10 \mathrm{~nm}$ GAM G10, and $15 \mathrm{~nm}$ GAM G15) was used to detect mouse monoclonal antibodies (Table 1). All procedures were performed at room temperature. Ultrathin sections $(60-70 \mathrm{~nm})$ on nickel grids (300 mesh) were incubated in the following solutions: (1) $0.1 \%$ sodium borohydride and $50 \mathrm{~mm}$ glycine in Trisbuffered saline containing $0.1 \%$ Triton X-100 (TBST; $10 \mathrm{~min}$ ); (2) $10 \%$ normal goat serum (NGS) in TBST (10 min); (3) polyclonal primary antibodies against GluR1, GluR2, GluR2/3, GluR4, mGluR1 $\alpha$, and calnexin or monoclonal primary antibodies against mGluR $1 \alpha$ and BiP (Table 1) in TBST containing 10\% NGS (2 hr); (4) TBST (10 min); (5) $10 \%$ NGS in TBST (10 min); and (6) colloidal gold-coupled secondary antibody diluted 1:20 in TBST containing 10\% NGS and polyethylene glycol $20,000(5 \mathrm{mg} / \mathrm{ml}, 1 \mathrm{hr})$. The ultrathin sections were counterstained with $1 \%$ uranyl acetate and $0.3 \%$ lead citrate and studied with a JEOL JEM-100CX II transmission electron microscope at $60 \mathrm{kV}$. Controls were performed by omitting the primary antibody. Also, preadsorption controls were performed by incubating the primary antibody plus 50 $\mu \mathrm{g} / \mathrm{ml}$ (final concentration) of the specific peptide, conjugated to BSA with glutaraldehyde, at $4^{\circ} \mathrm{C}$ for $24 \mathrm{hr}$, then centrifuging and incubating with the ultrathin sections.

Double labeling with polyclonal and monoclonal antibodies (Table 1) was performed in the same incubation step. Colloidal gold-coupled secondary antibody (5 $\mathrm{nm}$ anti-rabbit and 10 or $15 \mathrm{~nm}$ anti-mouse) diluted 1:20 in TBST containing 10\% NGS and polyethylene glycol $20,000(5 \mathrm{mg} / \mathrm{ml}, 1 \mathrm{hr})$ were incubated together.

Control experiments, in which the rabbit (GluR2/3, GluR4, and mGluR $1 \alpha$ ) antibody was incubated with the anti-mouse secondary antibody, or the mouse (mGluR1 $\alpha$ and BiP) antibody was incubated with the anti-rabbit secondary antibody, showed no immunoreactive labeling.

Double immunogold labeling using polyclonal antibodies (Table 1) was performed as described previously (Wang and Larsson, 1985; Matsubara et al., 1996; Landsend et al., 1997) using paraformaldehyde vapors between two sequential immunogold labeling procedures. Briefly, the first immunogold labeling was performed with a polyclonal antibody using colloidal gold-coupled goat anti-rabbit IgG (5 nm GAR G5, Amersham) as the secondary antibody. After $1 \mathrm{hr}$ treatment with parafor- 


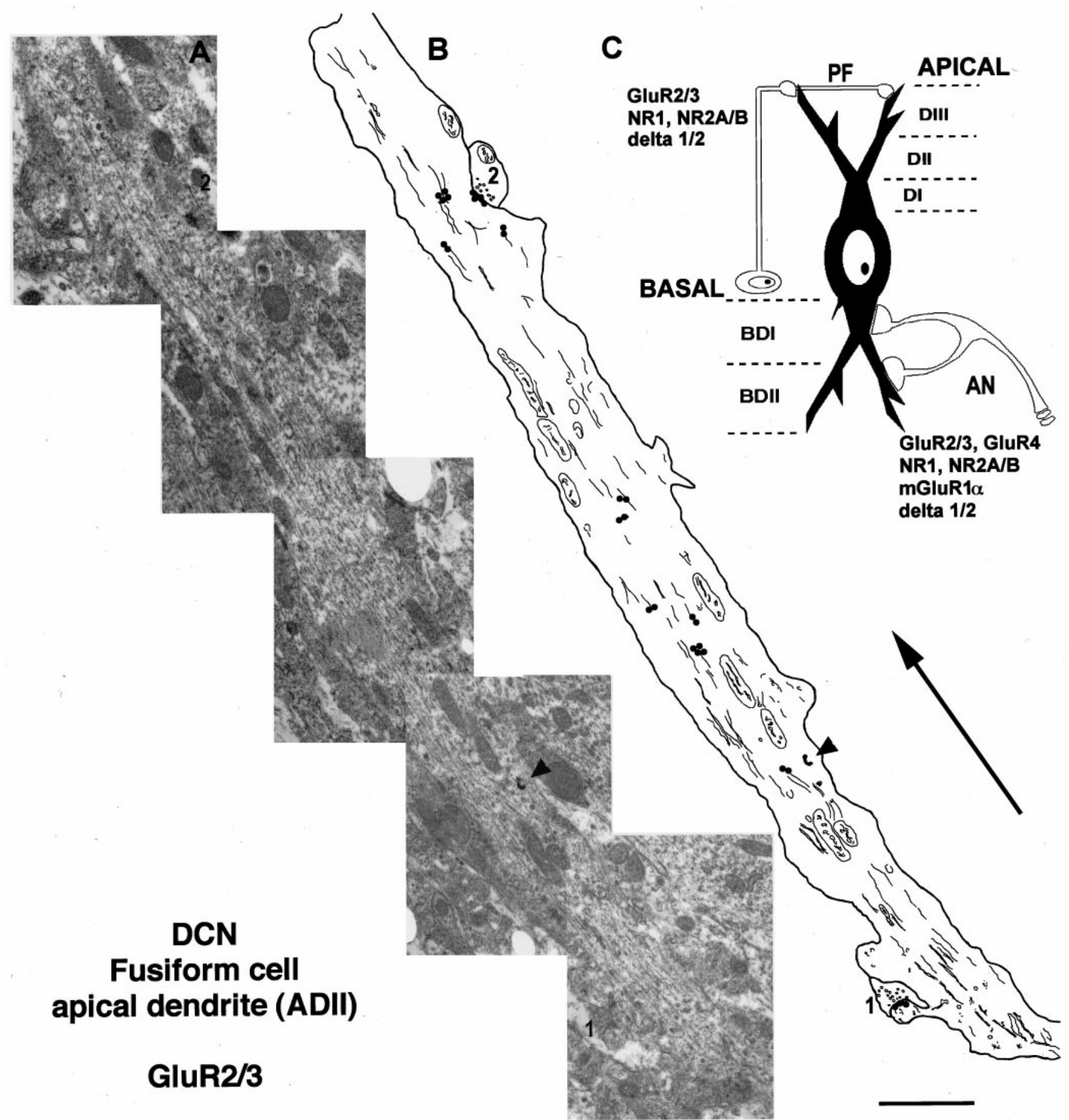

Figure 1. A, Electron micrograph montage of a secondary apical dendrite $(A D I I)$ of an FC of the dorsal cochlear nucleus $(D C N)$ after immunogold labeling $(5 \mathrm{~nm}$ gold) with a polyclonal antibody to GluR2/3 receptor subunits. Two parallel fiber synapses of the granule cells $(1,2)$ are observed making synaptic contact on a dendritic spine (1) and the dendritic shaft (2). An electron-dense granule of HRP (arrowhead) can be seen in the dendrite. $B$, Drawing of the same apical dendrite $(A)$ showing the synaptic [postsynaptic membrane of the parallel fiber synapses $(1,2)$ ] and subcellular location of gold particles labeling GluR2/3 subunits. The size of the gold particles has been increased for a better visualization. The lines inside the dendritic profile represent cytoskeleton and membranous structures. The arrow is oriented toward the surface of the DCN and away from the cell body. Scale bar, $2 \mu \mathrm{m}$. $C$, Schematic drawing showing the excitatory synaptic circuit on fusiform cells and the division of the apical and basal dendritic segments (see Results for more detail). Types and subunits of glutamate receptors expressed at the postsynaptic membrane of the auditory nerve $(A N)$ and parallel fibers of the granule cells $(P F)$ are indicated.

maldehyde vapors at $80^{\circ} \mathrm{C}$, the grids were washed with $\mathrm{H}_{2} \mathrm{O}$ and Trisbuffered saline containing $0.1 \%$ Triton $\mathrm{X}-100$. The second immunogold labeling was performed by incubating with a polyclonal antibody and using colloidal gold-coupled goat anti-rabbit (10 nm, Amersham) as secondary antibody.
All double immunogold labeling was repeated after changing the size of the gold particles. Control experiments were performed by omitting the primary antibody. An additional control consisted of omitting the primary antibody in the sequential immunogold labeling after the treatment with paraformaldehyde vapors. 


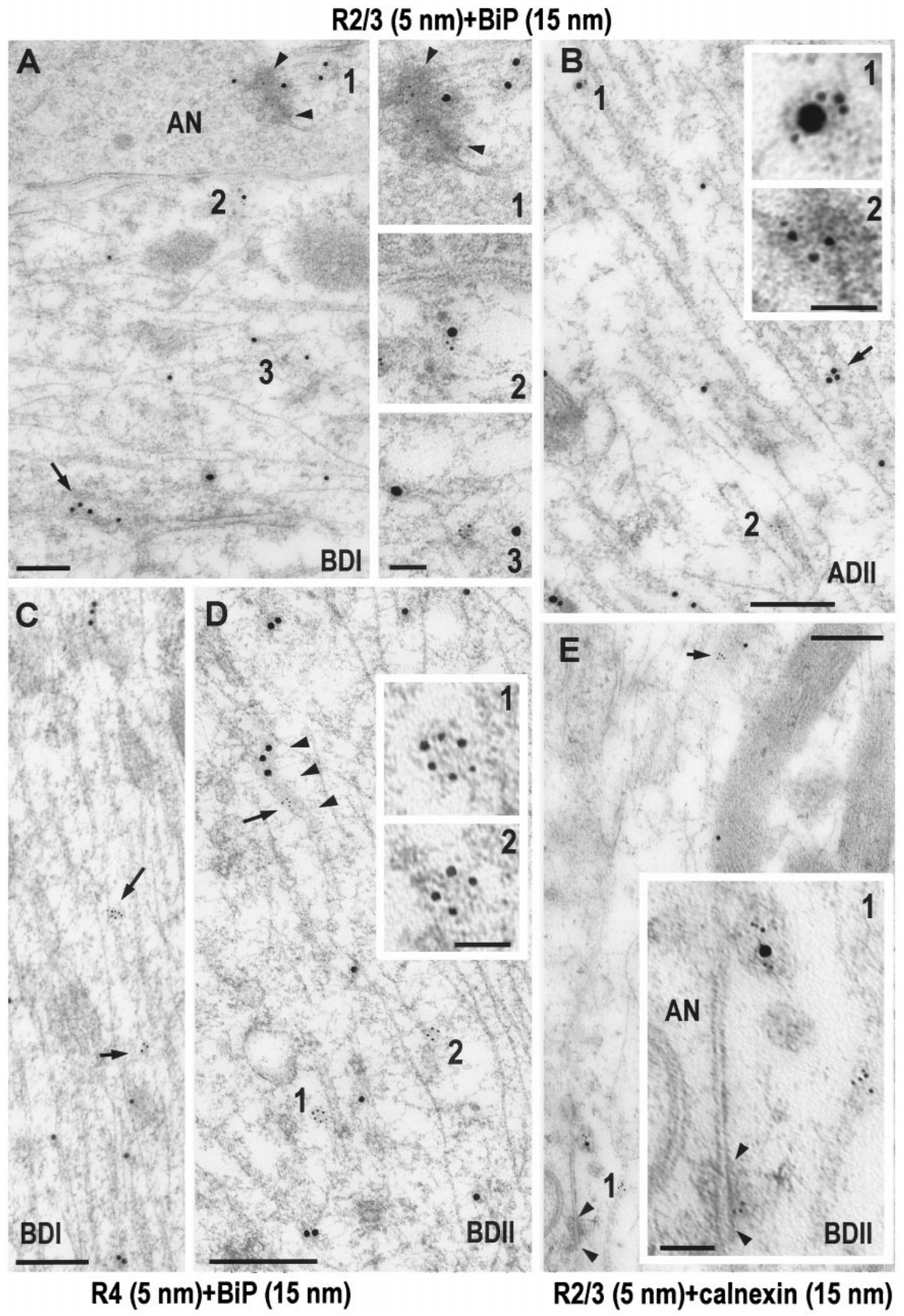

Figure 2. Double immunogold labeling with polyclonal antibodies for AMPA receptor subunits and BiP or calnexin in fusiform cell dendrites. $A$, $B$, Double immunogold labeling with a polyclonal antibody for GluR2/3 (5 nm) and a monoclonal antibody for BiP (15 nm) in a basal proximal dendrite $(A, B D I)$, and a secondary apical dendrite $(B, A D I I)$. In both dendrites, membranes of the endoplasmic reticulum immunogold-labeled with BiP (15 nm) as well as $5 \mathrm{~nm}$ gold particles for GluR2/3 antibody $(A, 1$ and $3 ; B, 1)$. Some membranes that labeled only for BiP (arrows in $A$ and $B$ ) and only for GluR2/3 $(B, 2)$ are also observed. In $A$, an auditory nerve terminal $(A N)$ is seen making synaptic contact on a dendritic (Figure legend continues) 
Electron micrographs were taken at $27,000 \times$ magnification and scanned using a 45 Leafscan (Leaf System, Southborough, MA). Treatment of the image was performed with AdobePhotoshop, using only the brightness and contrast commands to enhance the gold particles.

Identification of fusiform cell dendrites. Location and standard morphological characteristics were used to distinguish the different segments of apical and basal dendrites of FCs. In this study apical and basal dendrites were divided into three and two segments, respectively, depending on their branching and distance from the cell body. Only dendritic profiles presenting electron-dense granules of HRP in the same section or in the adjacent sections were considered in this study. All data were obtained from three different animals.

Apical dendrites are located in the upper portion of the fusiform cell layer above the cell bodies and in the molecular layer. It was not unusual to observe a thick dendritic segment, in continuity with the apical pole of the cell body and with ultrastructural characteristics similar to those that have been described previously for other bipolar neurons (Peters et al., 1991). These segments were considered to be primary apical dendrites (ADI). When dendrites were not observed in continuity with the cell body, only those dendritic profiles sharing the same location and thickness $(\sim 3.0 \mu \mathrm{m})$ were considered ADI. These dendrites have a cytoplasmic membrane without dendritic spines. In the same ultrathin section or in adjacent sections, ADI could be observed branching into thinner dendrites $(1.5-2 \mu \mathrm{m})$ that were identified as secondary dendrites (ADII). Ultrastructurally, ADII differ from ADI and from the cell body by the absence of rough endoplasmic reticulum (ER) and by the presence of some dendritic spines. Segments identified as distal or tertiary dendrites (ADIII, $\sim 70 \mu \mathrm{m}$ distal from the cell body) were located in the molecular layer and had spines receiving the parallel fiber input from granule cells (Rubio and Wenthold, 1997a).

Basal dendrites are located in the fusiform cell layer underneath the cell bodies and extend to the first third of the deep layer of the nucleus. Proximal basal dendrites (BDI) were considered to be all the fusiform cell dendrites identified with HRP, in the same or in adjacent ultrathin sections, that were located within the first $50 \mu \mathrm{m}$ from the cell body and were $\sim 4 \mu \mathrm{m}$ thick. These dendrites were often observed in continuity with the basal pole of the cell body. Distal basal dendrites (BDII) were located in the first third of the deep layer and were $\sim 1.5 \mu \mathrm{m}$ thick.

Identification of cartwheel cell dendrites. Cartwheel cells are the most numerous inhibitory interneurons in the dorsal cochlear nucleus (DCN). Their cell body and dendrites are located in the superficial or molecular layer of the nucleus. At the electron microscope level, we identified their dendrites on the basis of their characteristically spiny appearance and their multiple excitatory inputs from the parallel fibers of the granule cells (Wouterlood and Mugnaini, 1984).

Quantitative evaluation of glutamate receptor immunolabeling. The relative density of glutamate receptor immunolabeling in FCs of the dorsal cochlear nucleus was determined in a sample of 391 dendritic areas and 384 presynaptic areas. The sample included more than 20 areas for each of the dendritic profiles and for each of the antibodies analyzed. The sample of the presynaptic labeling included more than 70 areas for each of the antibodies.

In Purkinje cells of the cerebellum, the relative density of the GluR4 subunit of the AMPA glutamate receptors was determined in a total of 26 areas including cell bodies, dendrites, and dendritic spines. In the case of CA1 pyramidal cells of the hippocampus, a total of 25 areas were analyzed to calculate the relative density of mGluR $1 \alpha$ using the Ab-2 monoclonal antibody.

After the gold particles for each dendritic profile were counted, the perimeter of each dendritic segment was traced with the help of a digitizing Summagraphics tablet attached to a personal computer. Data were analyzed using morphometry software (Neurolucida, Microbright- field, Colchester, VT), which calculated the area of each profile. Once the number of gold particles and the area of each profile were known, the average density of gold particles was computed automatically for each type of dendritic or presynaptic profile.

Statistical comparison ( $t$ test, two-sample assuming unequal variances) was performed using the Microsoft Excel (4.0) program.

Quantitative evaluation of glutamate receptor immunolabeling as a function of distance from the synapse. The relative density of the GluR2/3 subunit of AMPA receptors as a function of distance from the auditory nerve synapse was determined in 296 areas of 15 basal dendrites of FCs as follows. Taking as zero the center of the postsynaptic density, arcs of $0.12 \mu \mathrm{m}$ intervals were drawn extending from the postsynaptic density to a distance of $2.64 \mu \mathrm{m}$. Gold particles per each dendritic arc profile were counted manually, and the perimeter of each dendritic segment was traced as described above. Using Neurolucida, the area of each profile was calculated. Once the number of gold particles and the area of each profile were known, the average density of gold particles was computed automatically for each of the dendritic arcs.

\section{RESULTS \\ Properties of glutamate receptors in fusiform cell dendrites}

To identify fusiform cells and their apical and basal dendrites, HRP was injected into the inferior colliculus of rats and allowed to retrogradely transport to the FCs (Rubio and Wenthold, 1997a). Only dendrites containing granules of HRP were analyzed.

For all glutamate receptors studied, gold particles were observed throughout the cytoplasm of dendrites (Fig. 1) and at the postsynaptic membranes of synapses formed with the auditory nerve and with parallel fibers, as described previously (Rubio and Wenthold, 1997a). Gold particles were often associated with smooth membranes, characteristic of the ER, which has been reported to extend from the cell body to the most distal dendrites, including dendritic spines (Spacek and Harris, 1997). To characterize further the nature of the intracellular membranes with which glutamate receptors are associated, we used double immunogold labeling for glutamate receptors and for specific proteins of the ER, BiP and calnexin (Villa et al., 1991; Krijnse-Locker et al., 1995; Torre and Steward, 1996; Gardiol et al., 1998). Immunofluorescence staining of BiP and calnexin in FCs showed that the ER was not restricted to the cell body but extended into both apical and basal dendrites in a reticular-like continuous pattern (data not shown). Postembedding immunocytochemistry showed that gold particles labeling for $\mathrm{BiP}$ and calnexin were associated with membranes in apical and basal dendrites and in dendritic spines of FCs (Fig. $2 A$ ). The membranes identified with the ER markers appeared to have a tubulovesicular-like shape and were found in the cytoplasm of dendrites, between cytoskeletal structures and around mitochondria. In some cases, labeling was seen near the postsynaptic density (Fig. 2A,E).

Double immunogold labeling with a polyclonal antibody to GluR2/3 and a monoclonal antibody to BiP or with a polyclonal antibody to calnexin showed that many of the membranes that

\section{$\leftarrow$}

spine (1) on basal dendrites. The postsynaptic membrane (arrowheads) contains $5 \mathrm{~nm}$ gold particles specific for GluR2/3, and the cytoplasm of the spine (1) contains $15 \mathrm{~nm}$ gold particles specific for BiP. C, D, Proximal (BDI) and distal (BDII) basal dendrites, respectively, after double immunogold labeling with a polyclonal antibody specific for GluR4 $(5 \mathrm{~nm})$ and a monoclonal antibody for BiP $(15 \mathrm{~nm})$. In both dendrites, membranes of the endoplasmic reticulum showed immunogold labeling for $\mathrm{BiP}(15 \mathrm{~nm})$ dispersed in the cytoplasm of the dendrite. Gold particles labeling GluR4 (5 nm; $D$, arrow) are associated with the same membranes labeled for BiP (arrowheads), but mostly are seen forming groups (C, arrows; $D, 1$ and 2$)$ of particles associated with membranes that do not contain labeling for BiP. E, Double immunogold labeling with a polyclonal antibody specific for GluR2/3 (5 nm) and calnexin $(15 \mathrm{~nm})$ in a distal basal dendrite $(B D I I)$ of a fusiform cell. Colocalization of 5 and $15 \mathrm{~nm}$ gold particles is observed in a vesicle-like structure close to the plasma membrane adjacent to an auditory nerve synapse $(A N)$. Gold particles labeling GluR2/3 are observed at the postsynaptic membrane of the auditory nerve (arrowheads) and in a smooth membrane in the cytoplasm (arrow). Insets show higher magnification of $A$ : 1-3. Scale bar, $0.25 \mu \mathrm{m}$; insets, $50 \mathrm{~nm} ; E, 0.12 \mu \mathrm{m}$. 


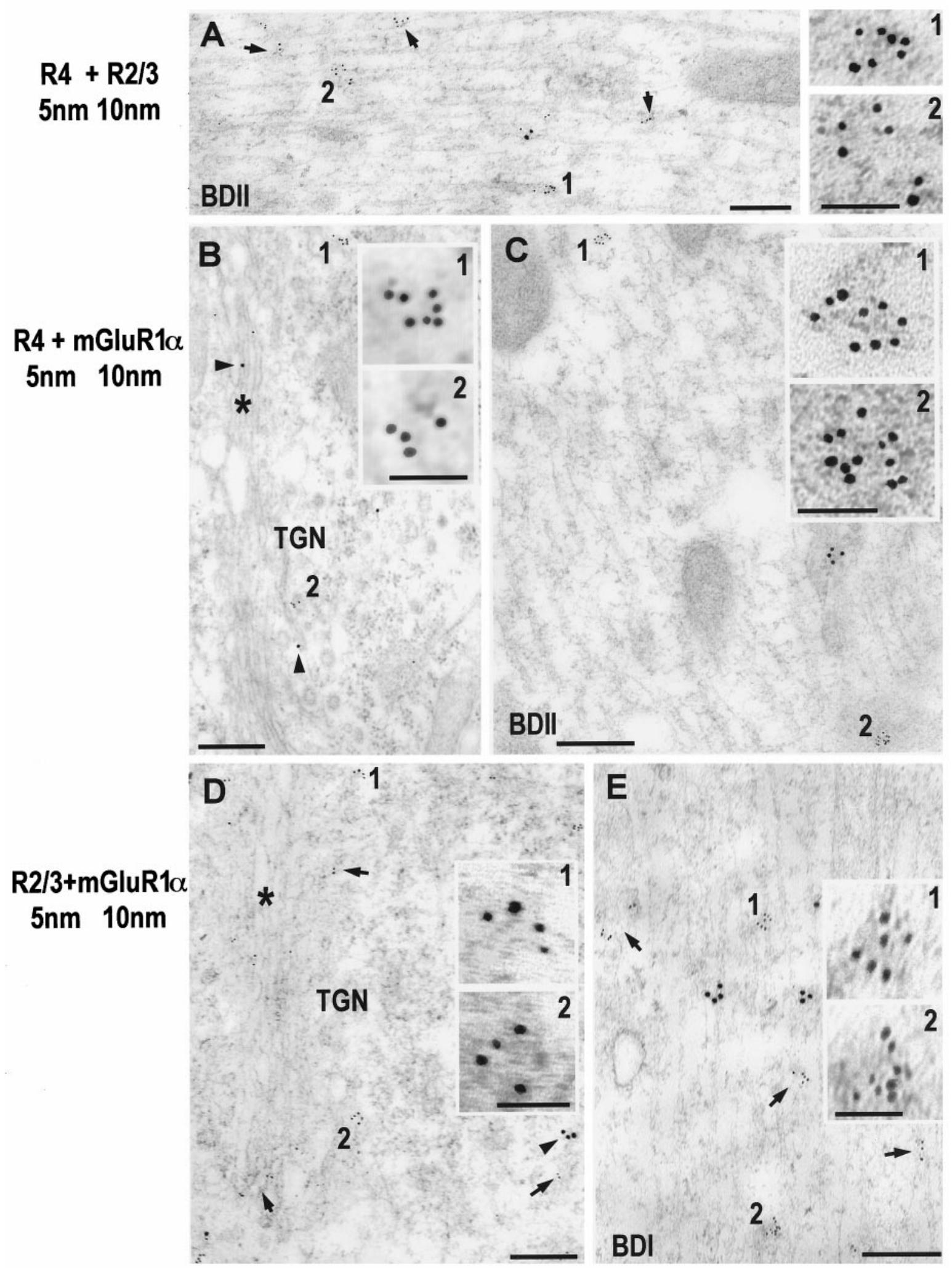

Figure 3. Double immunogold labeling of AMPA receptor subunits and metabotropic receptors in fusiform cells. $A$, Double immunogold labeling with polyclonal antibodies to GluR2/3 (10 nm gold) and GluR4 $(5 \mathrm{~nm}$ gold; arrows and 1, 2) in a distal basal dendrite (BDII). Clusters of gold particles (5 and $10 \mathrm{~nm}$ ) are observed distributed with a nonoverlapping pattern in the cytoplasm of the dendrite. $B, C$, Double immunogold labeling with polyclonal antibodies to GluR4 $(5 \mathrm{~nm})$ and mGluR1 $\alpha(10 \mathrm{~nm} ; \mathrm{Ab}-1)$ in the Golgi apparatus $\left({ }^{*}, B\right)$ in the basal pole of the cell body, and a basal distal dendrite $(B D I I$, $C)$. In the cell body $(B), 5 \mathrm{~nm}$ gold particles specific for GluR4 are observed organized in groups at the trans-Golgi network (TGN, 1). However, only single $10 \mathrm{~nm}$ gold particles are observed for mGluR1 $\alpha$ (arrowhead). In the BDII $(C)$, clusters of $5 \mathrm{~nm}(1,2)$ and $10 \mathrm{~nm}$ gold particles are observed in the cytoplasm, but there is no overlapping pattern in the distribution of these groups of gold particles. $D, E$, Double immunogold labeling with polyclonal antibodies to GluR2/3 $(5 \mathrm{~nm})$ and mGluR1 $\alpha(10 \mathrm{~nm} ; \mathrm{Ab}-1)$ in the Golgi apparatus (*, D) in the basal pole (Figure legend continues) 

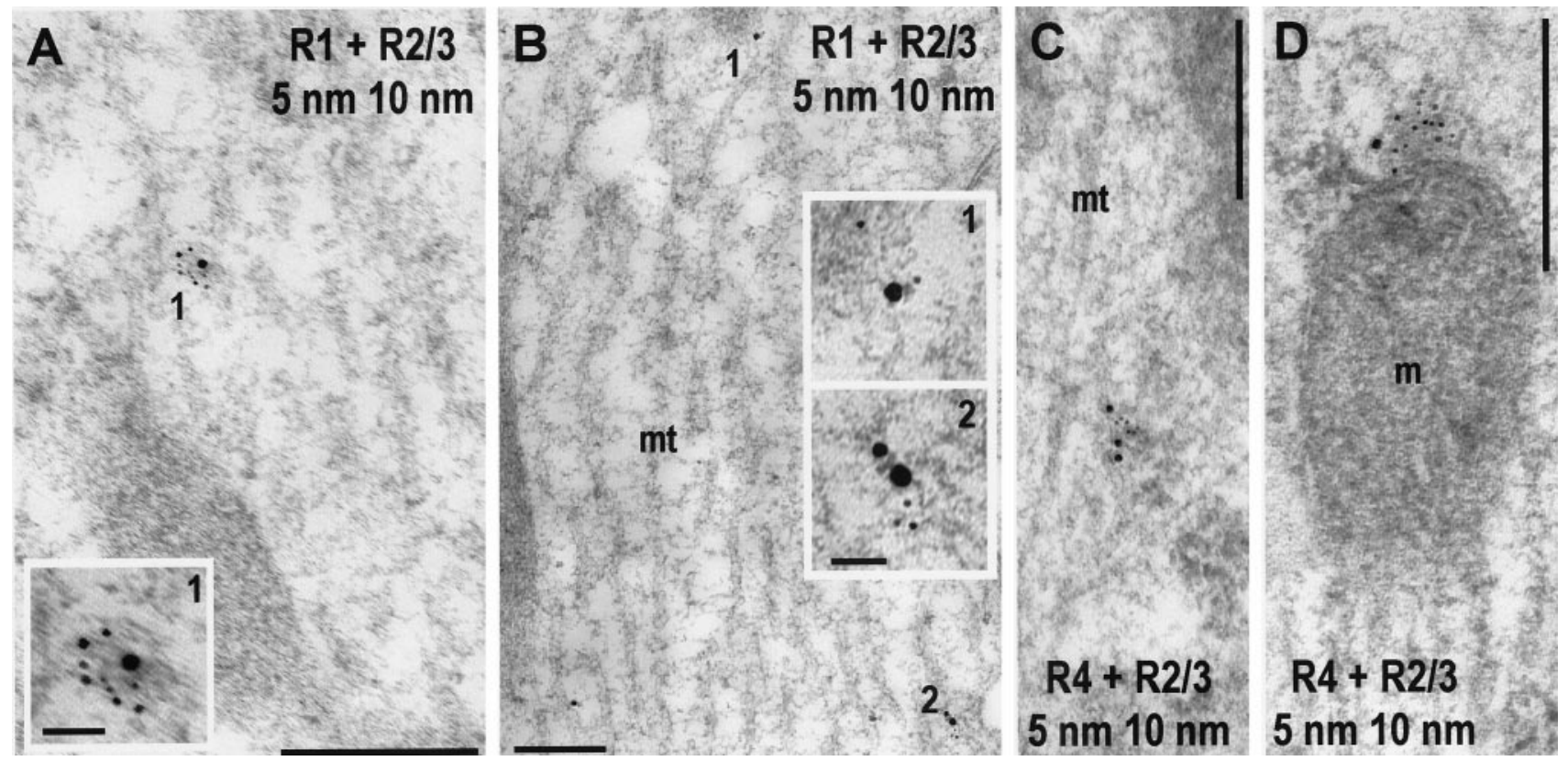

Figure 4. Double postembedding immunogold labeling using polyclonal antibodies to AMPA receptor subunits in cartwheel cells of the DCN. $A$, $B$, Two dendrites of cartwheel cells after immunogold labeling with polyclonal antibodies to GluR1 (5 nm) and GluR2/3 (10 nm). Colocalization of 5 and $10 \mathrm{~nm}$ gold particles $(1,2)$ is seen. Gold particles are observed associated with endoplasmic reticulum membranes and cytoskeletal structures. Insets show higher magnification of 1 and 2. $C, D$, Two dendrites of cartwheel cells after double immunogold labeling for GluR4 (5 nm) and GluR2/3 (10 nm). Colocalization of the 5 and $10 \mathrm{~nm}$ gold particles is observed in dendrites of cartwheel cells. $m t$, Microtubules; $m$, mitochondria. Scale bar, $0.25 \mu \mathrm{m}$; insets, $50 \mathrm{~nm}$.

were immunopositive for ER proteins also were immunopositive for GluR2/3 (Fig. 2A,B). However, in nearly half of the cases, GluR2/3 labeling was seen associated with membranes that were not immunogold-labeled for BiP or calnexin, both in apical and basal dendrites. A similar pattern of labeling was observed when we analyzed basal dendrites after double immunogold labeling for GluR4 or mGluR1 $\alpha$ with BiP (Fig. $2 C, D$ ) or calnexin (Fig. $2 E$ ). These results may suggest that there are at least two intracellular membrane populations, one associated with ER markers and the other not. However, we can only speculate about this conclusion, because immunogold labeling does not detect all of a particular antigen and because the double labeling results are not quantitative (Nusser et al., 1998; Petralia et al., 1999).

In analyzing the distribution of glutamate receptors in FC dendrites, we observed that labeling often occurred as groups of 2-12 gold particles (Figs. 2-7). This was seen for the AMPA receptor subunits and for mGluR $1 \alpha$. Such a pattern would support the idea that several receptors are organized together or are contained within a single organelle. Although we cannot rule out the alternative interpretation that the multiple gold particles are caused by several secondary antibodies binding to a single primary antibody, it is important to note that such a pattern is not present at the synapse, where labeling of receptors is often seen as a single row of a few gold particles. Furthermore, labeling of calnexin and $\mathrm{BiP}$ did not generate the multiple gold particle pattern in dendrites that was seen with receptors (Fig. 2). Similar patterns of labeling were seen in Purkinje cells and hippocampal pyramidal cells (data not shown), indicating that this phenomenon is not limited to FCs.

By double immunogold labeling, we analyzed the relationship between different receptors in the intracellular pool of basal FC dendrites (Fig. 3). In comparing the distributions of mGluR1 $\alpha$ and AMPA receptor subunits with double labeling (more than 50 cases were analyzed), we did not find both types of receptors in the same intracellular clusters, suggesting that these receptors are not packaged in the same organelles (Fig. $3 B-E$ ). In comparing the distributions of GluR2/3 and GluR4 (Fig. $3 A$ ), we also found no co-labeling of groups in the intracellular pool (more than 50 cases were analyzed). Because the AMPA receptor subunits are known to assemble into heteromeric complexes, our results suggest that GluR2/3 and GluR4 do not form complexes in FCs or that other factors, such as steric restraints, prevent labeling of multiple subunits in a complex. To examine this possibility, we studied the distribution of AMPA receptor subunits in the cartwheel cell, which is also present in the DCN and expresses multiple AMPA receptor subunits (Hunter et al., 1993; Petralia et al., 1996) (Fig. 4). The labeling was seen mostly in "groups" of gold particles associated with smooth membranes and cytoskeleton, as in FCs. However, unlike the pattern seen in FCs, in these groups colocalization of GluR1 and GluR2/3 or GluR2/3 and GluR4 was seen in $>50 \%$ of the cases. These results suggest that in FCs, GluR2/3 and GluR4 are packaged separately in dendrites,

\section{$\leftarrow$}

of the cell body and in BDI $(E)$. In the cell body $(D), 5 \mathrm{~nm}$ gold particles labeling the GluR2/3 subunit are observed forming groups of particles $(1,2)$ at the TGN. In the case of the antibody labeling mGluR1 $\alpha$, only single gold particles (arrowheads) are observed at the TGN, whereas groups of $10 \mathrm{~nm}$ gold particles are observed associated with the rough endoplasmic reticulum (arrowhead). In basal dendrites, groups of 5 and $10 \mathrm{~nm}$ gold particles are observed dispersed and associated with smooth membranes and cytoskeletal structures, with a nonoverlapping pattern. Insets show higher magnification of $5 \mathrm{~nm}$ gold clusters $(1,2)$. Scale bar, $0.25 \mu \mathrm{m}$; insets, $50 \mathrm{~nm}$. 

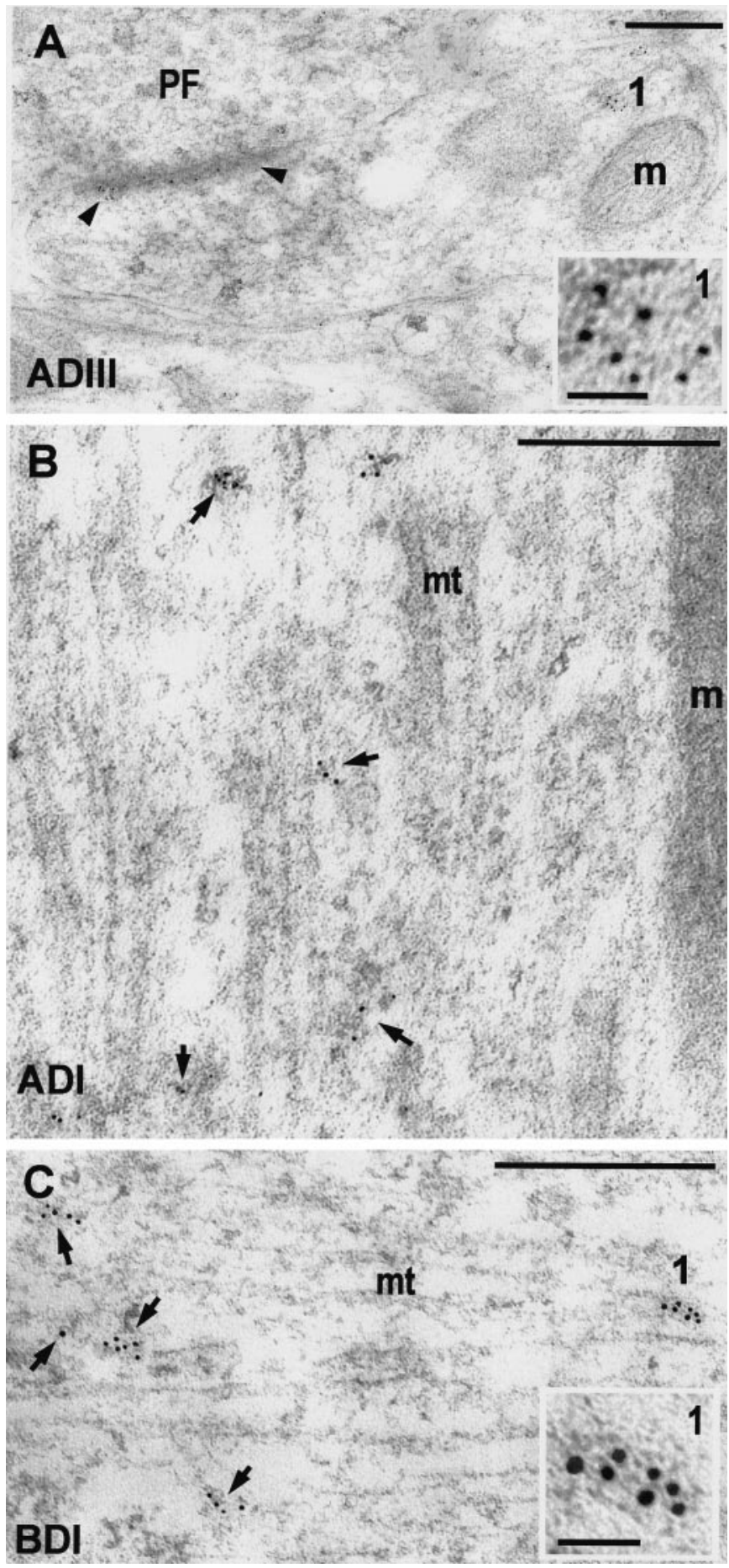

Figure 5. Postembedding immunogold labeling with a polyclonal antibody to GluR2/3 subunits ( $5 \mathrm{~nm}$ gold) in apical $(A, A D I I I ; B, A D I)$ and basal $(C, B D I)$ dendritic segments of fusiform cells. In all apical and basal dendritic segments, gold particles are observed as single particles or organized in groups distributed in the cytoplasm (arrows, 1). Smooth ER membranes and cytoskeleton are associated with these clusters of gold particles. $A$, A parallel fiber of the granule cells $(P F)$ is observed making synaptic contact on a dendritic spine of ADIII. The postsynaptic membrane appears immunogold-labeled ( $5 \mathrm{~nm}$; arrowheads). B, C, Apical and basal primary dendrites of FCs, respectively, showing the intracellular distribution of $5 \mathrm{~nm}$ gold particles for GluR2/3. Gold particles are observed as single particles or groups of particles that are associated with intracellular organelles. Insets show higher magnification of $5 \mathrm{~nm}$ gold particles (1). $m t$, Microtubules; $m$, mitochondria. Scale bar, $0.25 \mu \mathrm{m}$; insets, $50 \mathrm{~nm}$. leading to the conclusion that these subunits are not contained in a single receptor complex.

\section{The organization of intracellular glutamate receptors in FC dendrites}

Because the synaptic pattern of glutamate receptor labeling differs for apical and basal dendrite synapses in FCs, we can answer the question of whether the intracellular receptor pool is related to the synaptic receptors by comparing the distribution of intracellular receptors in apical and basal dendrites. As shown in Figure 1, FC dendrites were divided into zones based on their branching patterns and distance from the cell body. The distributions of the AMPA receptor subunits GluR2/3 (Fig. 5) and GluR4 (Fig. 6) and of the metabotropic receptor mGluR1 $\alpha$ (Fig. 7) were determined by measuring the density of gold particles in the different dendritic segments (Fig. 8). GluR2/3 labeling was present in all dendritic segments at a relatively high density of gold particles. Highest density was seen in the distal segments, ADIII and BDII, with lower $(p<0.01)$ values for the other segments. GluR4 labeling, seen only at the basal synapses (Rubio and Wenthold, 1997a), was significantly higher in the basal dendrite segments than in the apical segments $(p<0.01)$. A similar distribution pattern was seen for $\operatorname{mGluR} 1 \alpha$, which is also found only at the basal dendrite synapses.

One interpretation of these distribution results is that an intracellular pool of receptors is present near the synapse and that this pool can serve as a reserve for rapidly adding receptors to the synaptic membrane. To determine whether intracellular receptors are concentrated near the synapse, the density of GluR2/3 labeling as a function of distance from the synapse was determined. As shown in Figure 9, no selective accumulation of receptor was found associated with synapses. The correlation coefficient between the distance from the postsynaptic density and the density of gold particles was not statistically significant.

\section{Controls}

We used $5 \mathrm{~nm}$ colloidal gold to produce the highest possible signal. We also used more than one antibody to some receptors to ensure that the observed patterns are receptor specific. Although the number of antibodies to distinct epitopes on any one glutamate receptor is limited, similar patterns of intracellular distribution were seen for all receptors. Such patterns were different from those obtained with BiP and calnexin. For mGluR $1 \alpha$, three distinct antibodies were used and showed similar distribution patterns. Labeling with antibodies selective for GluR2 was similar to that with antibodies to GluR2/3. A series of routine controls, including omission of primary antibody in the first and sequential immunogold labeling and adsorption with the peptide conjugate, was performed for the AMPA receptor antibodies and the $\mathrm{C}$-terminus $\operatorname{mGluR} \alpha$ polyclonal antibodies. This resulted in essentially undetectable labeling in all cases.

Negative controls included assessment of labeling for receptors in presynaptic terminals and cells known to lack the receptors. As has been shown previously, quantification of the presynaptic gold particles showed very low labeling for antibodies to AMPA receptor subunits and mGluR1 $\alpha$ (Fig. 8, see legend). A large number of immunocytochemical, in situ hybridization, and single-cell PCR studies have identified neurons that do not express some of the glutamate receptors. For the AMPA receptors, GluR1, -3, and -4 , in particular, have limited patterns of expression. mGluR $1 \alpha$ is also expressed in a limited number of neurons. Cells that do not express a particular receptor serve as ideal controls for 


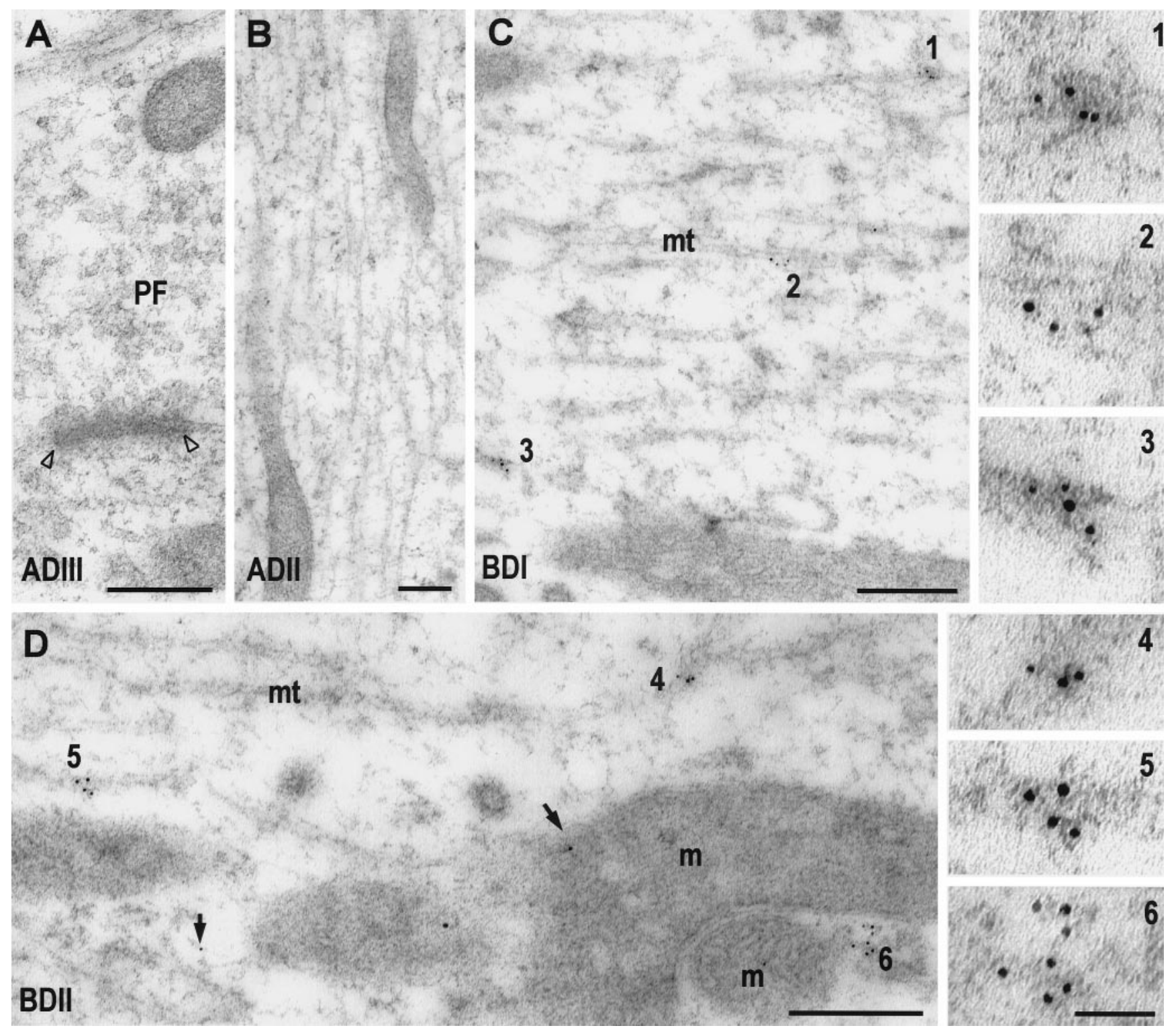

Figure 6. Postembedding immunogold labeling with a polyclonal antibody to GluR4 (5 nm gold) in apical $(A, A D I I I ; B, A D I I)$ and basal (C, $B D I ; D$, $B D I I)$ dendrites of fusiform cells. $A, B$, Two apical dendritic segments ( $A D I I I$ and $A D I I$, respectively) that lack immunogold labeling for GluR4. The micrograph of the ADIII $(A)$ also shows a parallel fiber synapse $(P F)$ of granule cells with an unlabeled postsynaptic membrane (open arrowheads). In basal dendrites, gold particles are mainly observed as single particles (arrows) or organized in groups $(C, B D I, 1-3 ; D, B D I I, 4-6)$. These groups of gold particles are associated with smooth membranes and cytoskeleton. Membranes with gold particles are often seen at the pole of mitochondria (6 in $D$, $B D I)$. Insets on the right show higher magnification of clusters of gold particles (1-6). $m t$, Microtubules; $m$, mitochondria. Scale bar, $0.25 \mu$ m; insets (1-6), $50 \mathrm{~nm}$.

immunocytochemical labeling because they can be used on the same preparations as the experimental labeling, thus avoiding possible differences between animals that can occur because of variations in fixation and tissue processing. In the present study, we used the Purkinje cell, which does not express GluR4 (Petralia and Wenthold, 1992), as a control for the labeling of GluR4 (Fig. 10 ), and the CA1 pyramidal cell of the hippocampus, as a control for the labeling of mGluR1 $\alpha$ (Petralia et al., 1997a). In analyzing subcellular labeling, gold particles labeling GluR4 and GluR1, which is expressed in very low levels in adult Purkinje cells (Petralia and Wenthold, 1992; Martin et al., 1993), were rarely seen in cytoplasm of dendrites or the cell body of Purkinje cells. We calculated the density of gold particles for GluR4 in different areas of dendrites and cell bodies of Purkinje cells, obtaining a very low level $\left(0.36 \pm 0.16 \mathrm{SEM}\right.$ gold particles $\left./ \mu \mathrm{m}^{2}\right)$. On the contrary, gold labeling was preferentially located in Bergmann glial, which express GluR1 and GluR4 (Petralia and Wenthold, 1992; Gallo and Russell, 1995) in processes that surround dendrites (Fig. 10A,B), dendritic spines (Fig. 10C,D), and cell bodies (data not shown) of Purkinje cells. We also obtained a very low density of gold particles $\left(0.27 \pm 0.09 \mathrm{SEM}\right.$ gold particles $\left./ \mu \mathrm{m}^{2}\right)$ for mGluR $1 \alpha$ in CA1 pyramidal neurons. These "background" values that we obtained for mGluR $1 \alpha$ and GluR4 are similar to the lowest values we found in fusiform cell dendrites.

\section{DISCUSSION}

The objective of the present work was to study the intracellular pool of glutamate receptors and determine whether the distribu- 

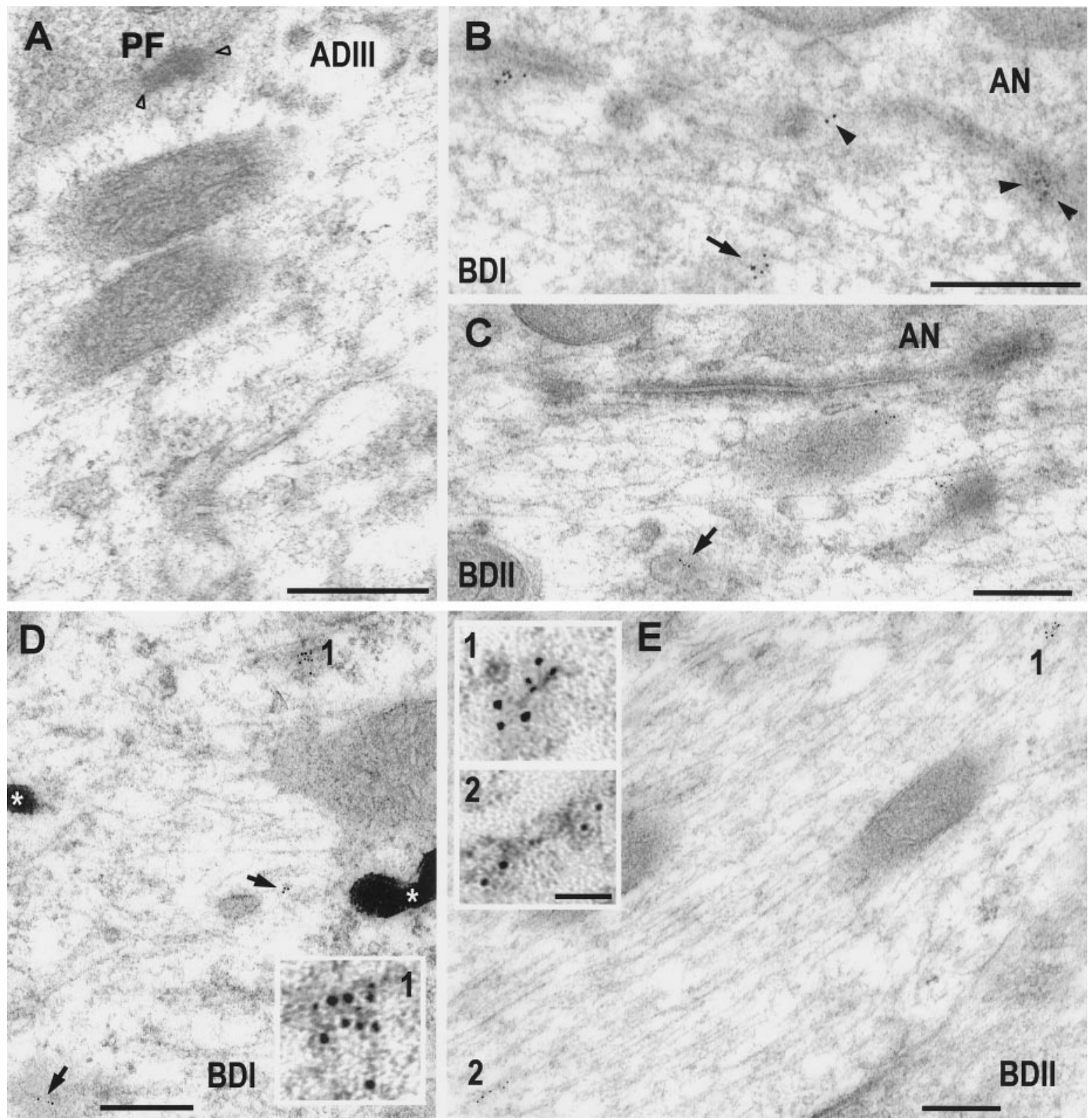

Figure 7. Postembedding immunogold labeling with two polyclonal antibodies and one monoclonal antibody to $\mathrm{mGluR} 1 \alpha(5 \mathrm{~nm}$ gold) in apical ( $A D I I I)$ and basal (BDI, BDII) dendrites of fusiform cells. $A$, Distal apical dendrite $(A D I I I)$ after the immunogold labeling with the polyclonal antibody Ab-1. Gold particles are not observed in the cytoplasm of the dendrite or on the postsynaptic membrane of the parallel fibers ( $P F$ ) of the granule cells (open arrowheads). The other four micrographs $(B-E)$ show basal dendrites after immunogold labeling with the monoclonal antibody Ab-2 (D, E) and the two polyclonal antibodies $(C, \mathrm{Ab}-1 ; B, \mathrm{Ab}-3)$ specific for mGluR1 $\alpha$. On basal dendrites $(B-E)$, gold particles are organized in clusters $($ arrows, 1,2$)$, and are associated with smooth membranes and cytoskeletal structures. Postsynaptic densities of auditory nerve synapses on basal dendrites contain gold particles $\left(B\right.$, arrowheads). Two electron-dense granules of HRP $\left(^{*}\right)$ are observed in the BDI $(D)$. Insets $(1,2)$ show higher magnification of $5 \mathrm{~nm}$ gold clusters. Scale bar, $0.25 \mu \mathrm{m}$; insets, $50 \mathrm{~nm}$.

tion of the intracellular pool is related to the synaptic distribution of the receptors. As a model neuron, we chose the FC of the dorsal cochlear nucleus, for which we have previously demonstrated that receptors are selectively targeted to synapses on apical and basal dendrites. From our present results, we can draw the following major conclusions. (1) The intracellular receptor pool is related to the synaptic pool. Receptors expressed only at basal dendrite synapses were relatively more abundant in intracellular pools in basal dendrites than in apical dendrites. Receptors expressed at both populations of synapses were equally abundant in intracellular pools of basal and apical dendrites.
These results suggest that a mechanism is present to selectively sort and target receptors soon after synthesis. (2) Although the pool of intracellular receptors reflects the synaptic pool, we find no evidence for an intracellular reserve of receptors that is concentrated near the synapse. Therefore, recruitment of synaptic receptors would involve receptors distributed throughout the dendrite. (3) Immunogold labeling suggests that intracellular receptors are organized in groups of several receptors. Different receptors, such as AMPA receptors and metabotropic receptors, are not present in the same groups. (4) Intracellular glutamate receptors were found associated with the tubulovesicular ER 


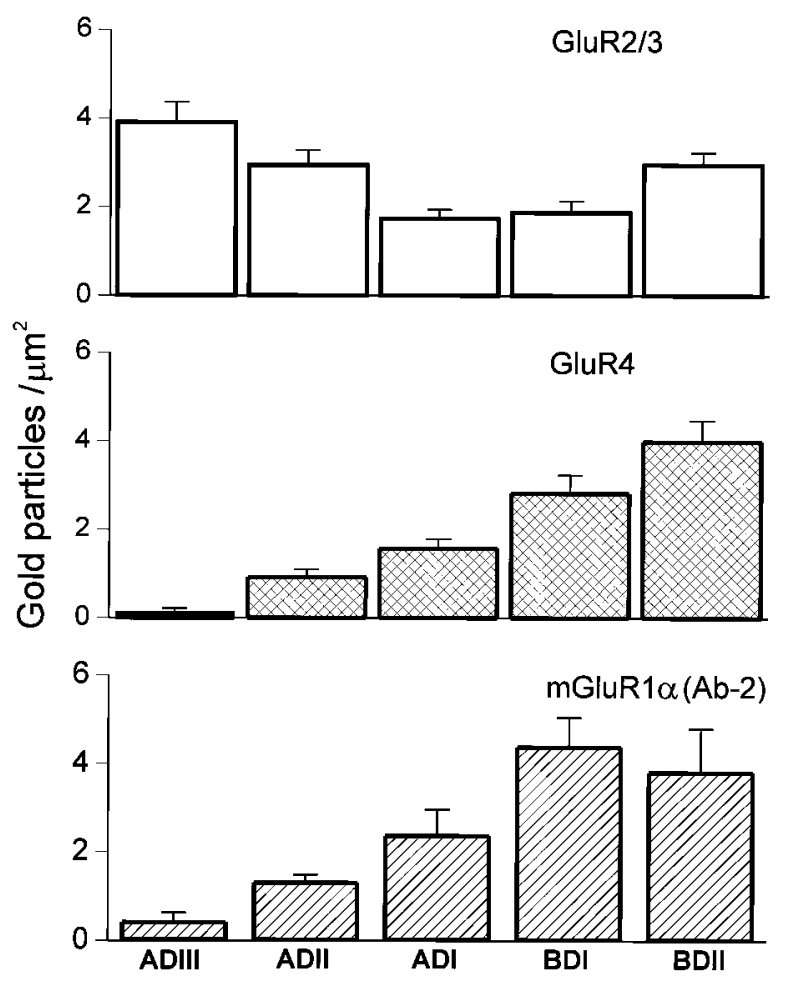

Figure 8. Histograms showing the relative density of gold particles and SEM for GluR2/3, GluR4, and mGluR1 $\alpha$ (Ab-2) in different dendritic segments of fusiform cells. GluR $2 / 3$ immunolabeling is present in all dendritic segments, but with the highest level in both distal apical and basal dendritic segments (the difference between these two distal dendritic segments is not statistically significant, $p>0.01$; the difference among the rest of the dendritic segments is statistically significant, $p<$ 0.01 ). On the other hand, only basal dendrites show relatively high levels for GluR4 and mGluR1 $\alpha$. The labeling decreases toward the apical distal dendrites and is statistically significant $(p<0.01)$. The density of gold particles was compared for all the dendritic segments, and the difference of gold labeling was statistically significant for all the cases $(p<0.01)$. As a control, we quantified the level of labeling in presynaptic areas adjacent to the dendrites of FC. The density ( \pm SEM) of gold particles in presynaptic terminals was the following: GluR2/3, $0.55 \pm 0.16$; GluR4, $0.92 \pm$ 0.23 ; and mGluR $1 \alpha, \mathrm{Ab}-1,1.30 \pm 0.43$; Ab-2, $1.16 \pm 0.27$. ADIII, Apical tertiary dendrite; $A D I I$, apical secondary dendrite; $A D I$, apical primary dendrite; $B D I$, proximal primary basal dendrite; $B D I I$, distal secondary basal dendrite.

membranes, indicating that this intracellular membrane system may represent the cytoplasmic organelle by which most intracellular receptors are transported throughout dendrites.

\section{Distribution of intradendritic glutamate receptors}

Based on the distribution of mRNA, glutamate receptors appear to be synthesized predominantly in the neuronal cell body (Eshhar et al., 1993; Hunter et al., 1993; Lauri and Seeburg, 1994; Bahn and Wisden, 1997). Therefore, receptor expression at the postsynaptic plasma membrane requires an effective mechanism to selectively move receptors to their appropriate locations throughout the somatodendritic compartment. The presence of relatively large intracellular pools of ionotropic and metabotropic glutamate receptors has been documented in many ways, including immunocytochemistry using immunoperoxidase, immunofluorescence and colloidal gold, biochemical approaches to quantify intracellular and surface receptors, and the use of green fluorescent protein (GFP) tagged to glutamate receptors in an in vitro assay (Petralia and Wenthold, 1992; Doherty et al., 1997; Hall and

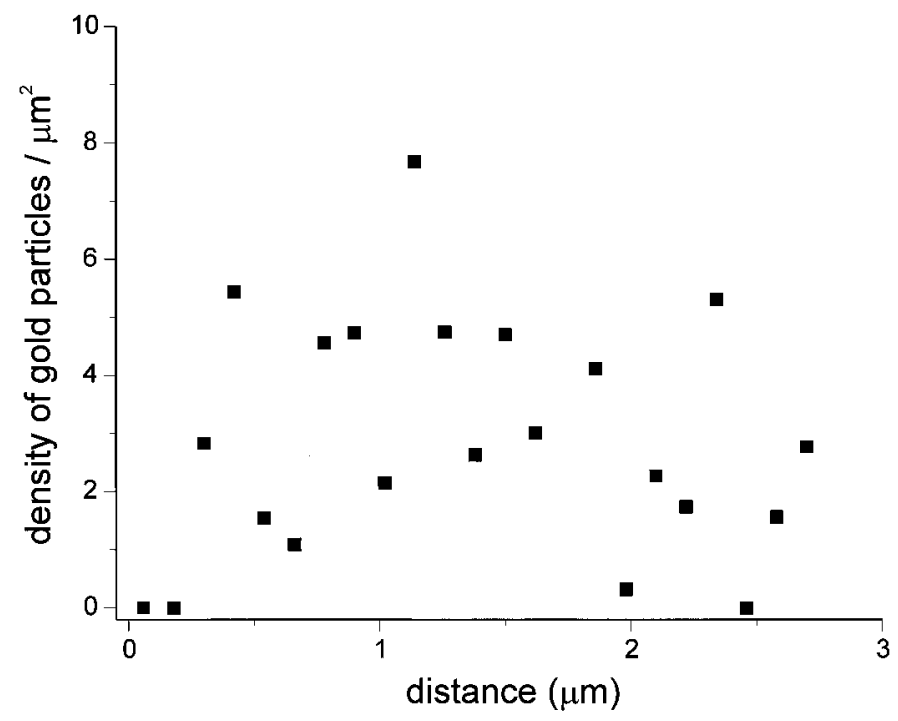

Figure 9. Histogram showing density of gold particles for GluR2/3 as a function of distance from the auditory nerve synapses on basal dendrites. The correlation coefficient between the density of gold particles and the distance from the PSD was not statistically significant $(r=0)$.

Soderling, 1997; Mammen et al., 1997; Huh and Wenthold, 1999). These studies indicate that $30-60 \%$ of AMPA receptors are associated with intracellular pools, which presumably are receptors that are destined for synaptic expression or have been removed from the synaptic membrane and are either being recycled or awaiting degradation.

Our analysis of the distribution of AMPA and metabotropic receptors in the dendrites of FCs shows that the intracellular receptor pool is related to the synaptic pool such that dendritic segments lacking a particular synaptic receptor have a much lower level of intracellular receptor. Such a distribution is consistent with a mechanism that targets receptors soon after synthesis. This differential targeting between two different dendritic segments can be compared with the compartmentalization that is found in other systems, such as polarized epithelial cells (Drubin and Nelson, 1996; Wozniak and Limbird, 1996) and axonal versus dendritic sorting that takes place in neurons and occurs at the level of the Golgi apparatus (Kelly and Grote, 1993).

Although the distribution in dendrites is consistent with the receptor being transported to the synapse, alternative explanations include the following possibilities. (1) The low level of intracellular receptor in dendritic branches that lack synaptic receptors could result from the selective degradation of receptors. Such a mechanism seems inconsistent with the generally long half-lives of AMPA and NMDA receptors ( $>1 \mathrm{~d}$ ) (Mammen et al., 1997; Huh and Wenthold, 1999), but it has recently been shown that a pool of unassembled NR1 is rapidly degraded in cultured granule cells (Huh and Wenthold, 1999). This may suggest the presence of a mechanism to degrade unnecessary receptors rapidly. (2) The pool of intracellular receptors may be made up predominantly of receptors that have been removed from the synaptic membrane and are being returned to the cell body for degradation. Evidence arguing against this are the recent GFP-tagged receptor experiments showing that the newly synthesized intracellular pool of receptors can be recruited to the synapse (Hayashi and Malinow, 1998).

In our analysis of the distribution of intracellular receptors, we did not find evidence for a pool of receptors concentrated near 


\section{GluR1}
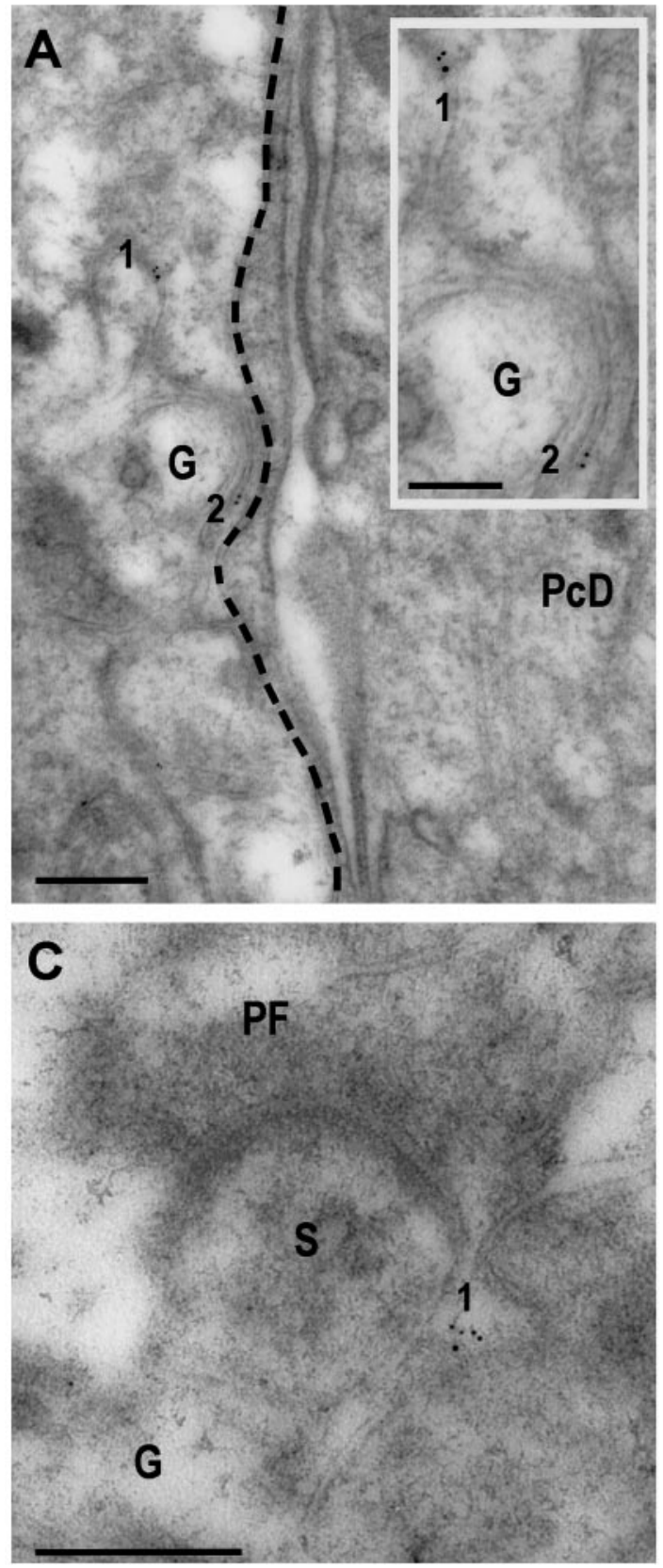

GluR4
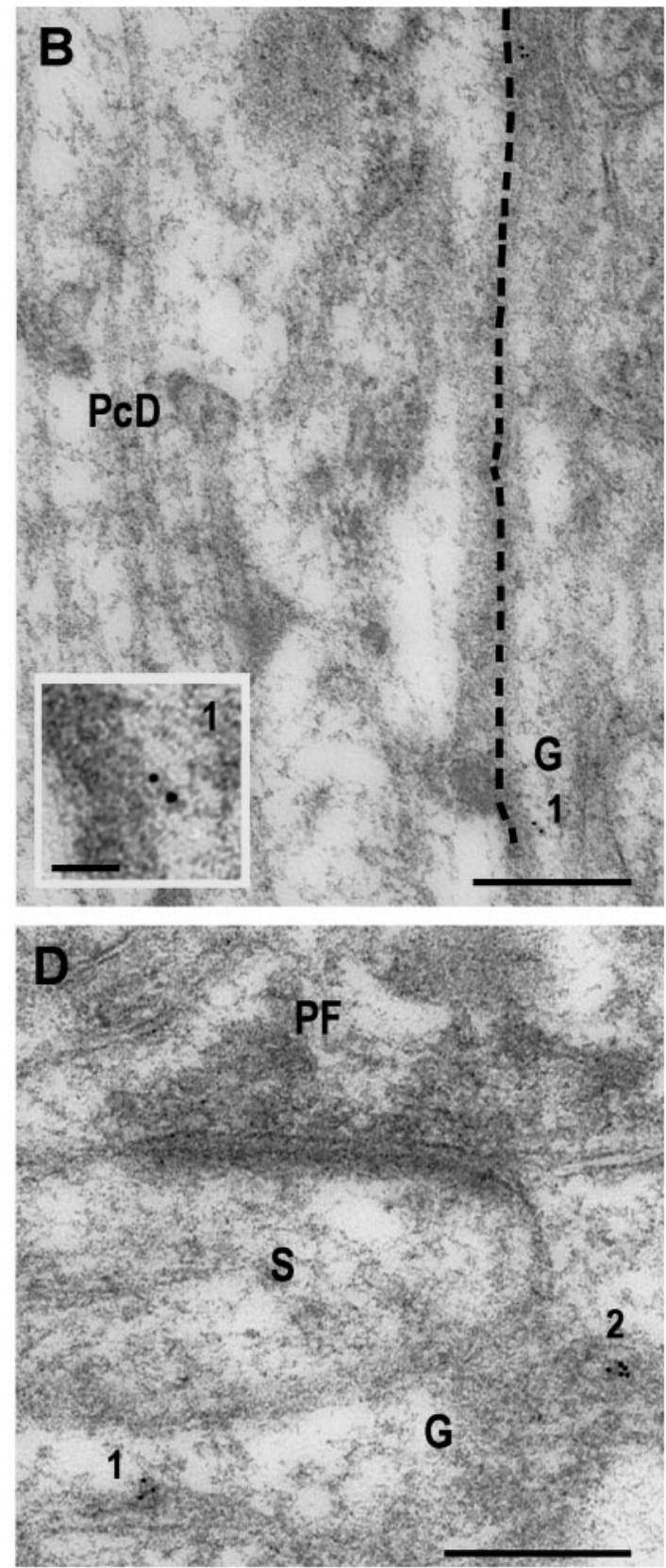

Figure 10. Postembedding immunogold labeling $(5 \mathrm{~nm})$ with polyclonal antibodies to GluR1 $(A, C)$ and GluR4 $(B, D)$ in the molecular layer of the cerebellum. $A, B$, Two primary dendrites of Purkinje cells $(P c D)$ and processes of Bergmann glia $(G)$ after immunogold labeling for GluR1 $(A)$ and GluR4 $(B)$. Only glial processes $(G)$ show immunogold labeling $(1,2)$. $C, D$, Two parallel fiber synapses $(P F)$ onto dendritic spines $(S)$ of Purkinje cells, surrounded with cytoplasmic processes of Bergmann glia $(G)$, after immunogold labeling for GluR1 $(C)$ and GluR4 $(D)$. Gold particles $(1$, 2) are observed only in the glia around the dendritic spine. Insets show a higher magnification of 1 and 2 in $A$ and $B$. Dashed lines in $A$ and $B$ are drawn to visualize better the limits between the dendrite of Purkinje cells and the neuropil. Scale bar, $0.25 \mu \mathrm{m} ;$ insets, $50 \mathrm{~nm} ; A, 0.12 \mu \mathrm{m}$.

the synapse. Such a pool has been postulated as a receptor reserve, which would allow a rapid insertion of additional receptors into the postsynaptic membrane. For example, long-term potentiation (LTP) (Liao et al., 1995; Nicoll and Malenka, 1995) has been suggested to involve the addition of AMPA receptors to the postsynaptic membrane, with a likely source of these receptors being an intracellular pool (Nayak et al., 1998; Shi et al., 1998). Because our results show a rather uniform distribution of receptors in the dendrite, recruitment of additional synaptic re- ceptors would involve obtaining receptors from throughout the dendrite. If the addition of intracellular receptors is a component of LTP or other mechanisms involving rather rapid changes, the dendrite must use a mechanism to efficiently move these receptors.

\section{The organization of intracellular receptors}

Our analysis of intracellular glutamate receptors using $5 \mathrm{~nm}$ colloidal gold showed that labeling often occurred as groups of 
gold particles, suggesting that several receptors were closely associated in dendrites. Because AMPA receptors are complexes of four or five subunits (Wenthold et al., 1992; Rosenmund et al., 1998; Rubio et al., 1998), theoretically an equal number of antibodies could bind to a complex if it is homomeric. It is unlikely that more than one antibody could bind to a subunit because the antibodies are made to small peptides of approximately 15 amino acids. A similar labeling pattern was seen for $\operatorname{mGluR} 1 \alpha$, which is believed to function as a single polypeptide. Another factor to consider is that multiple secondary antibodies could bind to a single primary to produce the clustered labeling pattern that we see. However, we think this is unlikely, because at synapses it is unusual to find gold particles at the numbers seen in the intracellular clusters. Often, one to three particles are associated with the entire postsynaptic density. Furthermore, BiP and calnexin staining in dendrites did not show a cluster pattern of staining, indicating that not all dendritic staining occurs in clusters. Our interpretation is that multiple receptor complexes are associated in the intracellular compartment.

\section{Intracellular receptors are associated with tubulovesicular endoplasmic membranes in dendrites}

It has been shown previously that membranes of the ER extend from the cell body to the most distal dendrites (Walton et al., 1991; Terasaki et al., 1994; Kharazia et al., 1996), including dendritic spines (Spacek and Harris, 1997), and that such membranes express ER and Golgi proteins (Gardiol et al., 1998; Jareb and Banker, 1998). The presence of these proteins in dendrites has been related to the local synthesis of some proteins (e.g., the $\alpha 1$ subunit of the glycine receptor), but it also indicates that proteins synthesized in the cell body could undergo posttranslational processing, such as glycosylation and assembly, in the dendrite. We find that the intracellular immunogold labeling of AMPA and metabotropic receptors was often associated with tubulovesicular membranes of the ER, identified by the presence of BiP or calnexin, indicating that this system could be a major route for the transport of dendritic proteins. The majority of long-distance organelle transport in axons and dendrites is thought to be achieved by the active movements of microtubuleassociated motor proteins, such as kinesins and cytoplasmic dyneins, along microtubule tracks (Hirokawa, 1998). Although characterization of organelle movement and associated proteins has been probed mostly in axons, there is evidence indicating that a similar mechanism occurs in dendrites, including the mixed orientation of microtubules in dendrites that support organelle transport (Baas et al., 1988; Overly et al., 1996), the identification of motor proteins of the kinesin family, such as KIFC2, and the observation in vitro that organelles can reverse direction by changing motor activation or association, or switch to another microtubule (Brady et al., 1982; Smith and Forman, 1988). Myosins, which are involved in organelle transport in many systems, are also found in dendrites and may also play a role in dendritic protein movement (Mermall et al., 1998).

In summary, we find that the intracellular distribution of receptors is related to the synaptic distribution of the receptor in general, such that dendritic branches with high levels of synaptic receptors also have relatively high levels of intracellular receptors. However, it seems unlikely that this mechanism alone can account for the highly organized synaptic receptor distribution. Rather, our results are consistent with the idea that targeting of proteins in dendrites is regulated at multiple levels. This would involve a general targeting step as we describe here, a local step at which receptor-containing organelles are moved to the synapse, and a step at which the receptors are stabilized at the synapse, which may involve interaction with an anchor, such as members of the PSD95/SAP90 family.

\section{REFERENCES}

Baas PW, Deitch JS, Black MM, Banker GA (1988) Polarity orientation of microtubules in hippocampal neurons: uniformity in the axon and nonuniformity in the dendrite. Proc Natl Acad Sci USA 85:8335-8339.

Bahn S, Wisden W (1997) A map of non-NMDA receptor subunit expression in the vertebrate brain derived from in situ hybridization histochemistry. In: The ionotropic glutamate receptors (Monaghan DT, Wenthold RJ, eds), pp 149-187. Totowa, NJ: Humana.

Baude A, Nusser Z, Roberts JDB, Mulvihill E, McIlhinney RAJ, Somogy $\mathrm{P}$ (1993) The metabotropic glutamate receptor (mGluR $1 \alpha)$ is concentrated at perisynaptic membrane of neuronal subpopulations as detected by immunogold reaction. Neuron 11:771-787.

Brady ST, Lasek RJ, Allen RD (1982) Fast axonal transport in extruded axoplasm from squid giant axon. Science 218:1129-1131.

Chaudhry FA, Lehre KP, van Lookeren Campagne M, Ottersen OP, Danbolt NC, Storm-Mathisen J (1995) Glutamate transporters in glia plasma membranes: highly differentiated localizations revealed by quantitative ultrastructural immunocytochemistry. Neuron 15:711-720.

Doherty AJ, Collingridge GL, Henley JM (1997) GFP fusion proteins and AMPA receptor trafficking. Biochem Soc Trans 25:540S.

Drubin DG, Nelson WJ (1996) Origins of cell polarity. Cell 84:335-344.

Eshhar N, Petralia RS, Winters CA, Niedzielski AS, Wenthold RJ (1993) The segregation and expression of glutamate receptor subunits in cultured hippocampal neurons. Neuroscience 57:943-964.

Gallo V, Russell JT (1995) Excitatory amino acid receptors in glia: different subtypes for distinct functions. J Neurosci Res 42:1-8.

Gardiol A, Racca C, Triller A (1998) Dendritic and postsynaptic protein synthetic machinery. J Neurosci 19:168-179.

Hall RA, Soderling TR (1997) Quantitation of AMPA receptor surface expression in cultured hippocampal neurons. Neuroscience 78:361-371.

Hayashi Y, Malinow R (1998) Synaptic surface delivery of AMPA type glutamate receptor monitored by rescue of GluR2 $(-/-)$ phenotype with GluR2-GFP fusion protein. Soc Neurosci Abstr 572:13.

Hirokawa N (1998) Kinesin and dynein superfamily proteins and the mechanism of organelle transport. Science 279:519-526.

Hjelle OP, Chaudhry FA, Ottersen OP (1994) Antisera to glutathione: characterization and immunocytochemical application to the rat cerebellum. Eur J Neurosci 6:794-804.

Huh K-H, Wenthold RJ (1999) Turnover analysis of glutamate receptors identifies a rapidly degraded pool of $N$-methyl-D-aspartate receptor subunit, NR1, in cultured cerebellar granule cells. J Biol Chem 274:151-157.

Hunter C, Petralia RS, Vu TH, Wenthold RJ (1993) Expression of AMPA-selective glutamate receptor subunits in morphologically defined neurons of the mammalian cochlear nucleus. $J$ Neurosci 13:1932-1946.

Jareb M, Banker G (1998) The polarized sorting of membrane proteins expressed in cultured hippocampal neurons using viral vectors. Neuron 20:855-867.

Kelly RB, Grote E (1993) Protein targeting in the neuron. Annu Rev Neurosci 16:95-127.

Kennedy MB (1997) The postsynaptic density at glutamatergic synapses. Trends Neurosci 20:264-268.

Kharazia VN, Wenthold RJ, Weinberg RJ (1996) GluR1immunopositive interneurons in rat neocortex. $J$ Comp Neurol 368:399-412.

Kim E, Cho K-O, Rothschild A, Sheng M (1996) Heteromultimerization and NMDA receptor-clustering activity of chapsyn-110, a member of the PSD-95 family proteins. Neuron 17:103-113.

Kornau H-C, Schenker LT, Kennedy MB, Seeburg PH (1995) Domain interaction between NMDA receptor subunits and the postsynaptic density protein PSD-95. Science 269:1737-1740.

Krijnse-Locker J, Parton RG, Fuller SD, Griffiths G, Dotti CG (1995) The organization of the endoplasmic reticulum and the intermediate compartment in cultured rat hippocampal neurons. Mol Biol Cell 6:1315-1332.

Landsend AS, Amry-Mogaddam M, Matsubara A, Bergersen L, Usami S, Wenthold RJ, Ottersen OP (1997) Differential localization of $\delta$ glutamate receptors in the rat cerebellum: co-expression with AMPA re- 
ceptors in parallel fiber-spine synapses and absence from climbing fiber-spine synapses. J Neurosci 17:834-842.

Lauri DJ, Seeburg PH (1994) Regional and developmental heterogeneity in splicing of the rat brain NMDAR1 mRNA. J Neurosci 14:3180-3194.

Liao D, Hessier NA, Malinow R (1995) Activation of postsynaptically silent synapses during pairing-induced LTP in CA1 region of hippocampal slice. Nature 375:400-404.

Mammen AL, Huganir RL, O’Brian RJ (1997) Redistribution and stabilization of cell surface glutamate receptors during synapse formation. J Neurosci 17:7351-7358.

Martin LJ, Blakstone CD, Levey AI, Huganir RL, Price DL (1993) AMPA glutamate receptor subunits are differentially distributed in rat brain. Neuroscience 53:327-358.

Matsubara A, Laake JH, Davanger S, Usami S, Ottersen OP (1996) Organization of AMPA receptor subunits at a glutamate synapse: a quantitative immunogold analysis of hair cell synapses in rat organ of Corti. J Neurosci 16:4457-4467.

Mermall V, Post PL, Mooseker MS (1998) Unconventional myosins in cell movement, membrane traffic, and signal transduction. Science 279:527-533.

Nayak A, Zastrow DJ, Lickteig R, Zahniser NR, Browing MD (1998) Maintenance of late-phase LTP is accompanied by PKA-dependent increase in AMPA receptor synthesis. Nature 394:680-683.

Nicoll RA, Malenka RC (1995) Contrasting properties of two forms of long-term potentiation in the hippocampus (1995). Nature 377:115-118.

Nusser Z, Lujan R, Laube G, Roberts JDB, Elek Molnar E, Somogyi P (1998) Cell type and pathway dependence of synaptic AMPA receptor number and variability in the hippocampus. Neuron 21:545-559.

Overly CC, Rieff HI, Hollenbeck PJ (1996) Organelle motility and metabolism in axons vs dendrites of cultured hippocampal neurons. J Cell Sci 109:971-980.

Peters A, Palay SL, Webster H deF (1991) The fine structure of the nervous system. Neurons and supporting cells. New York: Oxford UP.

Petralia RS (1997) Immunocytochemical localization of ionotropic glutamate receptors (GluRs) in neural circuits. In: The ionotropic glutamate receptors (Monaghan DT, Wenthold RJ, eds), pp 219-263. Totowa, NJ: Humana.

Petralia RS, Wenthold RJ (1992) Light and electron immunocytochemical localization of AMPA-selective glutamate receptors in the rat brain. J Comp Neurol 318:329-354.

Petralia RS, Wang Y-X, Zhao H-M, Wenthold RJ (1996) Ionotropic and metabotropic glutamate receptors show unique postsynaptic, presynaptic, and glial localizations in the dorsal cochlear nucleus. J Comp Neurol 372:356-383.

Petralia RS, Wang Y-X, Singh S, Wu C, Shi L, Wei J, Wenthold RJ (1997a) A monoclonal antibody shows discrete cellular and subcellular localizations of mGluR $1 \alpha$ metabotropic glutamate receptors. J Chem Neuroanat 13:77-93.

Petralia RS, Wang Y-X, Mayat E, Wenthold RJ (1997b) Glutamate receptor subunit 2-selective antibody shows a differential distribution of calcium-impermeable AMPA receptors among populations of neurons. J Comp Neurol 385:456-476.
Petralia RS, Esteban JA, Wang Y-W, Partridge JG, Zhao H-M, Wenthold RJ, Malinow R (1999) Selective acquisition of AMPA receptors over postnatal development suggests a molecular basis for silent synapses. Nat Neurosci 2:31-36.

Rosenmund C, Stern-Bach Y, Stevens CF (1998) The tetrameric structure of a glutamate receptor channel. Science 280:1596-1599.

Rubio ME, Wenthold RJ (1997a) Glutamate receptors are selectively targeted to postsynaptic sites in neurons. Neuron 18:939-950.

Rubio ME, Wenthold RJ (1997b) BiP and calnexin co-immunoprecipitate with AMPA receptors. Soc Neurosci Abstr 923:4.

Rubio ME, Beuron F, Steven AC, Wenthold RJ (1998) Visualization of native AMPA receptor complexes. Soc Neurosci Abstr 340:12.

Shi S-H, Hayashi Y, Zaman S, Svoboda K, Malinow R (1998) Clustering of GluR1 induced by tetanic stimulation in hippocampal slices neurons. Soc Neurosci Abstr 8:11.

Smith RS, Forman DS (1988) Organelle dynamics in lobster axons: anterograde and retrograde particulate organelles. Brain Res 446:26-36.

Somogyi P, Tamás G, Luján R, Bulh EH (1998) Salient features of synaptic organisation in the cerebral cortex. Brain Res Rev 26:113-135.

Spacek J, Harris KM (1997) Three dimensional organization of smooth endoplasmic reticulum in hippocampal CA1 dendrites and dendritic spines of the immature and mature rat. J Neurosci 17:190-203.

Terasaki M, Slater NT, Fein A, Schmidek A, Reese TS (1994) Continuous network of endoplasmic reticulum in cerebellar Purkinje neurons. Proc Natl Acad Sci USA 91:7510-7514.

Torre ER, Steward O (1996) Protein synthesis within dendrites: glycosylation of newly synthesized proteins in dendrites of hippocampal neurons in culture. J Neurosci 16:5967-5978.

van Lookeren Campagne M, Oestreicher AB, van der Krift TP, Gispen WH, Verkleij AJ (1991) Freeze-substitution and Lowicryl HM20 embedding of fixed rat brain: suitability for immunogold ultrastructural localization of neural antigens. J Histochem Cytochem 39:1267-1279.

Villa A, Podini P, Clegg DO, Pozzan T, Meldonesi J (1991) Intracellular $\mathrm{Ca}^{2+}$ stores in chicken Purkinje neurons: differential distribution of the low affinity-high capacity $\mathrm{Ca}^{2+}$ binding protein, calsequestrin, of $\mathrm{Ca}^{2+}$ ATPase and of the ER lumenal protein, BiP. J Cell Biol 113:779-791.

Walton PD, Airey JA, Sutko JL, Beck CF, Mignery GA, Südhof TC, Deerink T, Ellisman M (1991) Ryanodine and inositol triphosphate receptors coexist in avian cerebellar Purkinje neurons. J Cell Biol 113:1145-1157.

Wang B-L, Larsson L-I (1985) Simultaneous demonstration of multiple antigens by indirect immunofluorescence or immunogold staining. Novel light and electron microscopical double and triple staining method employing primary antibodies from the same species. Histochemistry 83:47-56.

Wenthold RJ, Yokotani N, Doi K, Wada K (1992) Immunochemical characterization of the non-NMDA glutamate receptor using subunitspecific antibodies. J Biol Chem 267:501-507.

Wouterlood FG, Mugnaini E (1984) Cartwheel neurons of the dorsal cochlear nucleus: a Golgi-electron microscope study in rat. J Comp Neurol 227:136-157.

Wozniak M, Limbird LE (1996) The three $\alpha 2$-adrenergic receptor subtypes achieve basolateral localization in Madin-Darby Canine Kidney II cells via different targeting mechanisms. J Biol Chem 271:5017-5024. 